\title{
ロウ石鉱床に産出する鉱石の耐火 物原料としての検討
}

Roseki-Minerals as Refractory Materials

福 井 哲* (Satoshi Fukui)

1. まえがき

ロウ石鈗床から採据されている鉱石は，耐火物，陶磁器，クレ一等の原料 として使用され，耐火物関保丈けでも年間約 30 万屯利用されているので陶 磁器, クレー関係を含めると年間 40 万屯以上と推定される。従つて日本の 割業関係の原料としては重要なものである。

一般にロウ石鉱床は珪化帯，口ウ石帯，ダイアスポア一帯等に区分して考 えられているが，これらの各鉱帯の鉱物組成は鉱山により特有なもので，主 としてロウ石の多い部分, $\mathrm{Al}_{2} \mathrm{O}_{3}$ の含有の多いもの (ダイアスポフー帯) が利用され他は捨られている現状である。

実際にロウ石鉱床を調べてみると，珪化帯が非常に大きく，実際に利用さ れているロウ石帯は極めて小部分で，ダイアスポフー帯などは工業用原料と して利用されるものは殆んどないといら鉱山が多い。（五島鉱山には多量の ダイアスポアーが産出している)。

この莫大な鉣量のある珪化帯がどこまで，利用出来るかが今後の問題で鉱 物の未利用資源の活用といら観点からもまた鉱山の経営上からも重要な問題 と考えられる。

筆者は従来，口ウ石釯床に産する鉣石について興味をもち特に珪化帯を耐 火物原料に利用して来たので，如何なる観点からこれらの鉱石を検討するか について述べることにする。

\section{2. ロウ石鉱床に産する鉱物について}

日本のロウ石鉱床において見られる鉱物は，各鉱山により各特徵がある

* 関東窯業株式会社 
が，耐火物原料として利用する立場から鉱物を分類してみると次の如く考え られる。

2-1. $\mathrm{Al}_{2} \mathrm{O}_{3}$ の含有量の多いもの。

Diaspore $\left(\alpha-\mathrm{Al}_{2} \mathrm{O}_{3} \mathrm{H}_{2} \mathrm{O}\right)$, Boehmite $\left(\gamma-\mathrm{Al}_{2} \mathrm{O}_{3} \mathrm{H}_{2} \mathrm{O}\right)$, Corundum $\left(\alpha-\mathrm{Al}_{2}\right.$ $\left.\mathrm{O}_{3}\right)$, Andalusite $\left(\mathrm{Al}_{2} \mathrm{O}_{3} \mathrm{SiO}_{2}\right)$, Gibbsite $\left(\mathrm{Al}_{2} \mathrm{O}_{3} \quad 3 \mathrm{H}_{2} \mathrm{O}\right)$. 。

このらち産出量が多く工業原料として使用されているのはダイアスポアー 丈で他のものは鉱物として存在はするが利用される程の量がない。

2-2. 揮発性物質を含有するもの

Zunyite $\left(\mathrm{Al}_{13} \mathrm{Si}_{5} \mathrm{O}_{20}(\mathrm{OH}, \mathrm{F})_{18} \mathrm{Cl}\right)$, Dumortierite $\left(8 \mathrm{Al}_{2} \mathrm{O}_{3} \mathrm{~B}_{3} \mathrm{O}_{3} 6 \mathrm{SiO}_{2}\right.$ $\left.\mathrm{H}_{2} \mathrm{O}\right)$, Topaz [Al (F.OH) $\left.)_{2}\right] \mathrm{SO}_{4}$, Tourmaline.

デンキ石の存在は焼成後黒色班点を作るので好ましくない。（鉄化合物を 含有するので.......)。ズニアイト, デュモルティェライトは共に $\mathrm{Al}_{3} \mathrm{O}_{2}$ の含 有量が多く且つ焼結性がよいので貴重な鉱物である。何れも原石を焼成する ことによって耐火度が増すものである。ズニアイトは一時金倉鉱山より産出 し利用された。デュモルティエライトは五島鉱山より月産 10 屯ぐらい産出 するので工業的に利用価值がある。

2-3. $\mathrm{Al}_{2} \mathrm{O}_{3}-\mathrm{SiO}_{2}$ 系のもの

Pyrophyllite $\left(\mathrm{Al}_{2} \mathrm{O}_{3} 4 \mathrm{SiO}_{2} \mathrm{H}_{2} \mathrm{O}\right)$, Kaolinite $\left(\mathrm{Al}_{2} \mathrm{O}_{3} 2 \mathrm{SiO}_{2} 2 \mathrm{H}_{2} \mathrm{O}\right)$, Dickite $\left(\mathrm{Al}_{2} \mathrm{O}_{3} 2 \mathrm{SiO}_{2} 2 \mathrm{H}_{2} \mathrm{O}\right)$, Sericite $\left(\mathrm{K}_{2} \mathrm{O} \quad 3 \mathrm{Al}_{2} \mathrm{O}_{3} 6 \mathrm{SiO}_{2} 2 \mathrm{H}_{2} \mathrm{O}\right)$, Montmorillonite $\left(\mathrm{Al}_{2} \mathrm{Si}_{4} \mathrm{O}_{10}(\mathrm{OH})_{2} \mathrm{nH}_{2} \mathrm{O}\right)$, Feldspar $\left(\mathrm{R}_{2} \mathrm{O} \quad \mathrm{Al}_{2} \mathrm{O}_{3} 6 \mathrm{SiO}_{2}\right), \mathrm{Al}-$ unite $\left(\mathrm{K}_{2} \mathrm{O} \quad 3 \mathrm{Al}_{2} \mathrm{O}_{3} 4 \mathrm{SiO}_{2} \mathrm{O}\right)$, Chlorite ( $\mathrm{MgO}$ を含む粘土鉱物)

ロウ石はこの鉣床の主要成分である。これ以外のものは小量或は微量存在 しこの小量或は微量存在するものが鉱石の利用活用に大きく影響するもので ある。

$\mathrm{Al}_{2} \mathrm{O}_{3}-\mathrm{SiO}_{2}$ 系のものでは $\mathrm{R}_{2} \mathrm{O}\left(\mathrm{K}_{2} \mathrm{O}, \mathrm{Na}_{2} \mathrm{O}\right.$ を示す）を含むものがあり， これは焼結材の役目をするので微量存在することは望ましいが存在のしかた が問題である。大きな粒子の形ではなく微粒子で且つ一様に分布しているこ とが望ましい。

ロウ石鉱床で一番闍題になるのはセリサイトである。

2-4 Ti, $\mathrm{Fe}$ を含むもの

Pyrite (FeS), Hematite $\left(\mathrm{Fe}_{2} \mathrm{O}_{3}\right)$, Limonite $\left(\mathrm{Fe}_{2} \mathrm{O}_{3} \mathrm{nH}_{2} \mathrm{O}\right)$, Illmenite ( $\mathrm{FeO} \mathrm{TiO}_{2}$ ). 
これらは何れも焼成品に対して着色するか黑色の斑点となるので好ましく ない。特にオウテッ鉣, チタンテッ鉣は存在しないことが望ましい。

鉄の含有量は, $\mathrm{Fe}_{2} \mathrm{O}_{3}$ として $3 \%$ 以下が望ましく焼成すことによって黒 色の斑点を生じない状態となるものは使用可能である。

\section{2-5 セキェイについて}

このセキエイが問題で，粒子の大きさ,分布状況, 变質の程度等が他の諸鉣 物と如何椂に存在するかといらことが利用する立場から問題となってくる。

2-6 耐火物原料としての鉱物について,

耐火物原料として考える場合，必要な条件は鉣石の鉙量の多いこと，鉱石 の品質の均一，鉱石の原料として適否といらことである。

今これを鉱物的に観ると，七キェイ，パイロフィライト，ダイアスポアー 等が主要組合鉣物でこれに前記の種々の鉣物が少肯或は微量存在しているも のである。これらの鉱石が耐火物原料に適するか否かを決定する方法を検討 してみることにする。

\section{3. 耐火物原料の検討方法}

一般に鉱石が耐火物原料として利用出来るか否かを検討するのに種々な方 法が用いられているが，筆者は次の如き方法によっている。

3-1 耐火性

耐火物といらからには耐火性が必要で，先づ耐火度を测定する”。耐火度 は SK (Seger Cone) 何番として表わすが一応 SK18，(1500 $\left.{ }^{\circ} \mathrm{C}\right)$ 以上のも のは使用が出来るとして限定しておこう。 SK18 以下でも特殊の目的に利 用出来るものもある。

\section{3-2 焼成試験}

次の如き二種類の試料を作る。

a 試料 試料の製作条件として粉末度 $2 \mathrm{~mm}$ 篩全通, 成形圧力 $300 \mathrm{~kg} / \mathrm{cm}^{2}$, 大きさ $50 \times 50 \varphi \mathrm{mm}$ のもの。

$\mathrm{b}$ 試料 原石から塊状のまま $40 \sim 50 \mathrm{~mm}$ 解大のものを切り出したもの。 この $\mathrm{a}, \mathrm{b}$ 二種類を適当な温度（例えば $1200 ， 1300 ， 1400,1500^{\circ} \mathrm{C}$ の如 くに）に焼成して，その焼結性，膨脹收縮性，色調，龟裂の有無或は黑色の 班点の有無等により判断してレンガに製作したときの状沉を検討する。 
焼結性は気孔率，吸水率，比重，圧縮強さ等により，膨脹收縮性は\%によ って表わしている。

一般には $\mathrm{a}$ 試料丈けで試験しているが筆者は $\mathrm{a}, \mathrm{b}$ 二種のものについて試 験している。この理由は次の如くである。

耐火物の原料となるには暁成することによって低気孔性（例えば気孔率20 \%以下）となることが必要条件である。

$\mathrm{a}, \mathrm{b}$ 二種類の試料を同一条件で焼成した場合に $\mathrm{a}$ 陚料で低気孔性となる ものは勿論利用される可能性があるが，低気孔性とならなくとも $\mathrm{b}$ 試料で低 気孔性となるものについては粗粒子として利用される可能性がある。

以上のことは特に珪化帯の高珪酸質の鉱石の利用については実験してみる 可きことである。

3-3 X 線回折及び偏光顕微鏡による検討。

前にのべた如く，口ウ不鉣床に産出する鉱物は主成分としてはセキェイ， パイロフィライト， $\mathrm{Al}_{2} \mathrm{O}_{3}$ 含有量の多いもの等であるから，その他の少量 成分の検討はX $\mathrm{X}$ 線によらなければならない。湿微鏡観察では判定出来ないセ リサイトとパイロフィライトの区別が必要で, 更にカオリナイト，モンモリ ロナイト，その他の鉱物の確認もしておくことが望ましい。

$\mathrm{X}$ 線回折による鉱物の検討も必要であるが，それよりも鉱物の組織の検討 が更に重要と考える。これ汇偏光顕微鏡による以外にはない。即ち主要組 成鉱物であるセキエイ，パイロフライト，ダイアスポア等の結晶粒子の大 きさ, 分布状況, 变質の程度等を調べることが鉣石の利用活用の要点である。

\section{3-4 化学分折}

ロウ石鉱石では, 化学分析により主として $\mathrm{Al}_{2} \mathrm{O}_{3} \quad \mathrm{SiO}_{2} \quad \mathrm{Fe}_{2} \mathrm{O}_{3} \quad \mathrm{R}_{2} \mathrm{O}$ 等を 調べ, $\mathrm{R}_{2} \mathrm{O}$ の含有跙の多いものは特別の注意を要する。それは口ウ石中に セリサイトが多く含まれていることを示すもので $\mathrm{R}_{2} \mathrm{O} 4 \%$ 以下のものが望 ましい。

\section{4. 利用活用の問題点と実用例について}

鉣石を利用活用する場合の問題点と実用例並にそれに附随したことについ て述べる。

$4-1$ 七リサイトについて

従来偏光顕徽鏡丈けではセリサイトとパイロフィトとの区別が出来がない 
ので僅かに化学分析によってセリサイトが存在することを推定していたにす ぎなかった。その時代はパイロフィライトがあるから燒結性が良好と考兄ら れていたがX線回折の利用が盛んとなりまたセりサイトの研究も進み容易に セリサイトが調べられる様になり，焼結性の良いロウ石はセリサイトを含む ことが知れた。更にこのセリサイトの少量が耐火レンガの性質に及ぼす影響 も検討され少量存在することは耐侵蝕性にも好結果であることが知れた。

現在では取鍋レンガにセキェイ質のものでセリサイトの含まれた鉣石が利 用され好結果を得ている現状である。

現在耐火物原料として探している鉱石は口ウ石鉣床に伴ら七キェイ質のも のでこれにパイロフィライト，セリサイト，カオリナイト等適当量あるもの で, SK18 以上あれば可成利用される見込がある。故に陶石もセキェイと セリサイトの組織如何により十分利用されることが知れている。

\section{4-2 鉣物組成について}

耐火物原料として鉱石を観る場合には次のことが大切なことである。

(a) 組成鉱物の均一性

(b) 結晶粒子が細かくその分布が一様なこと。

（c）不適当と考えられる鉱物が少量であること。

耐火物では原料が $100 \%$ 製品となるので a, b 共に必要な項目で製品の品 質管理上重要なことである。

ロウ石では $\mathrm{R}_{2} \mathrm{O}\left(\mathrm{K}_{2} \mathrm{O}, \mathrm{Na}_{2} \mathrm{O}\right)$ の含有量の変動, セキェイ粒子大きさ及 びその具の增減が常に品質管理上問題となっている。

前節で顕微鏡による鉣物の組織の検討の重要性をのべたが更に詳細につい て述べる。

例 1 . 化学分析值では $\mathrm{Al}_{2} \mathrm{O}_{3}, \mathrm{SiO}_{2}, \mathrm{Fe}_{2} \mathrm{O}_{3}$ 等が大体同一であっても, こ れに含有されているセキェイの粒子の大きさ，分布状態がどのようであるか によって原料の性質が非常に違ったものとなることはよく見受けるところで ある。

筆者の経験ではセキェイ粒子の結唱の大きさは $0.5 \mathrm{~mm}$ 以下を希堭し好 ましい状態は $0.0 \mathrm{n} . \mathrm{mm}$. 大で揃っているもの，そしてセキェイとパイロフ イライト（セリサイトを含む）とが一様に分布しているものである。

例 2.ダイアスポアとパイロフィライト，

一般のダイアスポア結晶は顕微鏡下では大きいものは 0.n.m. 大のもの 
がありその周辺をパイロフィライトが散在している形のもの, 或はダイアス ポアのみの集合した形のもの，更にダイアスポアとセキエイ粒子とが共存す るもの等があるが，原料的立場からは結晶粒子は $0.0 \mathrm{n} . \mathrm{mm}$. 以下のものが 望ましい。

最も良好なものは三石太平鉣山の特級口ウ石の如き，ダイアスポアとパイ ロフィライトとが $0.00 \mathrm{n} . \mathrm{mm}$. ぐらいの極めて微細な粒子で極めて均一に混 合し合った状況にあるものである。従ってダイアスポフの鉣石といえば硬い と考えられるが，この特級口ウ石は口ウ石の少し硬いぐらいのもので粉砕さ れやすいものである。

例 3.ダイアスポアとセキェイ,

山口県の某ロウ石鉣山のダイアスポア鉱石は $0.1 \mathrm{~mm}$ 大のダイアスポア の結晶と約 $0.1 \mathrm{~mm}$ の七キエイ粒子と, それに少量のパイロフィライトの あるもので顕微鏡で見た丈けで，化学分析上 $\mathrm{Al}_{2} \mathrm{O}_{3}$ が多くとも不良の鉱石 ということが判断出来るものもある。

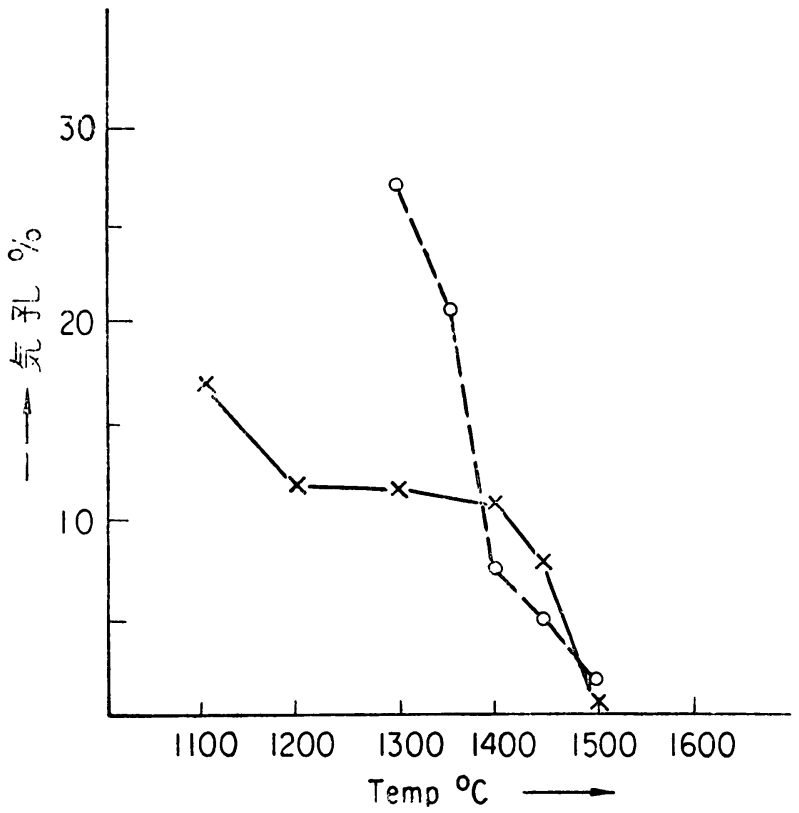

第 1 図 焼成温度別飞上る気孔率 $\times \cdots \cdots .$. 月形 $\bigcirc \cdots \cdots . .$. 奈古 
ー 256ー 口ウ石鉱床に産出する鉱石の耐火物原料としての検討

4-3 実用例について

4-3-1 奈古珪岩について

ロウ石鉱床に伴って産出する珪岩で耐火度を测定すると SK27 である。 粉砕したものを成形した試料, 及び原石から切り出した塊状の試料の両者を SK14 15 辺で焼成したところ両者共気孔率 10\% 以下となった。一応焼結 性よりみて耐火物原料となり得ると推定される。なお, 焼成温度別による気 孔率の低下の状況は第 1 囯に示寸如く, $1300^{\circ} \mathrm{C}$ から $1500^{\circ} \mathrm{C}$ ぐらい迄に 急激な焼結をなす。

化学分析值は第 1 表の如くである。

第 1 表 奈古けい岩化学分析值

\begin{tabular}{|c|c|c|c|c|c|c|}
\hline Ig loss & $\mathrm{SiO}_{2}$ & $\mathrm{Al}_{2} \mathrm{O}_{3}$ & $\mathrm{Fe}_{2} \mathrm{O}_{3}$ & $\mathrm{CaO}$ & $\mathrm{MgO}$ & Total \\
\hline 1. 76 & 83. 92 & 11. 16 & 0.79 & 0.26 & 0.23 & 98.12 \\
\hline
\end{tabular}

この剑石の組成鉱物を $\mathrm{X}$ 線回折及び偏光顕微鏡によって調べると大部分がセ キエイで少量のセリサイト，パイロフィライト，アンダリニサイト等からな り，X線のピークより判定するとセりサイトがパイロフィライトよりはるか に多く存在している。そして鉱物の状況はセキェイが $0 . \mathrm{n} \sim 0.0 \mathrm{n} . \mathrm{mm}$. 大の ものが大体一様に分布しておりセキェイ粒子間をセリサイト（パイロフィラ イトを含む）が一様に充填している形で，そしてアンダリューサイトの多い 部分も存在している。（写真 1 参照）

このものは造塊用レンガ原料としては良好なものである。

5-3-2 月形ロウ石について

福島県産のもので従来耐火物原料としては殆んどかえりみられなかてたも のであったが調べてみると耐火度は SK27, 化学分析值は第 2 表の如くであ る。

第 2 表 月形ロウ石化学分析值

\begin{tabular}{r|r|r|r|r|r|c}
\hline Ig loss & \multicolumn{1}{c|}{$\mathrm{SiO}_{2}$} & \multicolumn{1}{c|}{$\mathrm{Al}_{2} \mathrm{O}_{3}$} & \multicolumn{1}{c|}{$\mathrm{Fe}_{2} \mathrm{O}_{3}$} & \multicolumn{1}{c}{$\mathrm{CaO}$} & \multicolumn{1}{c}{$\mathrm{MgO}$} & \multicolumn{1}{c}{ Total } \\
\hline 4.90 & 75.66 & 16.99 & 0.16 & 0.16 & 0.22 & 98.09 \\
\hline
\end{tabular}

今顕微鏡と X線回折によってその組成釷物並にその組織を調べるとセキェ イが大部分で,このほかパイロフィライト, セリサイトとより成り, セキェ 

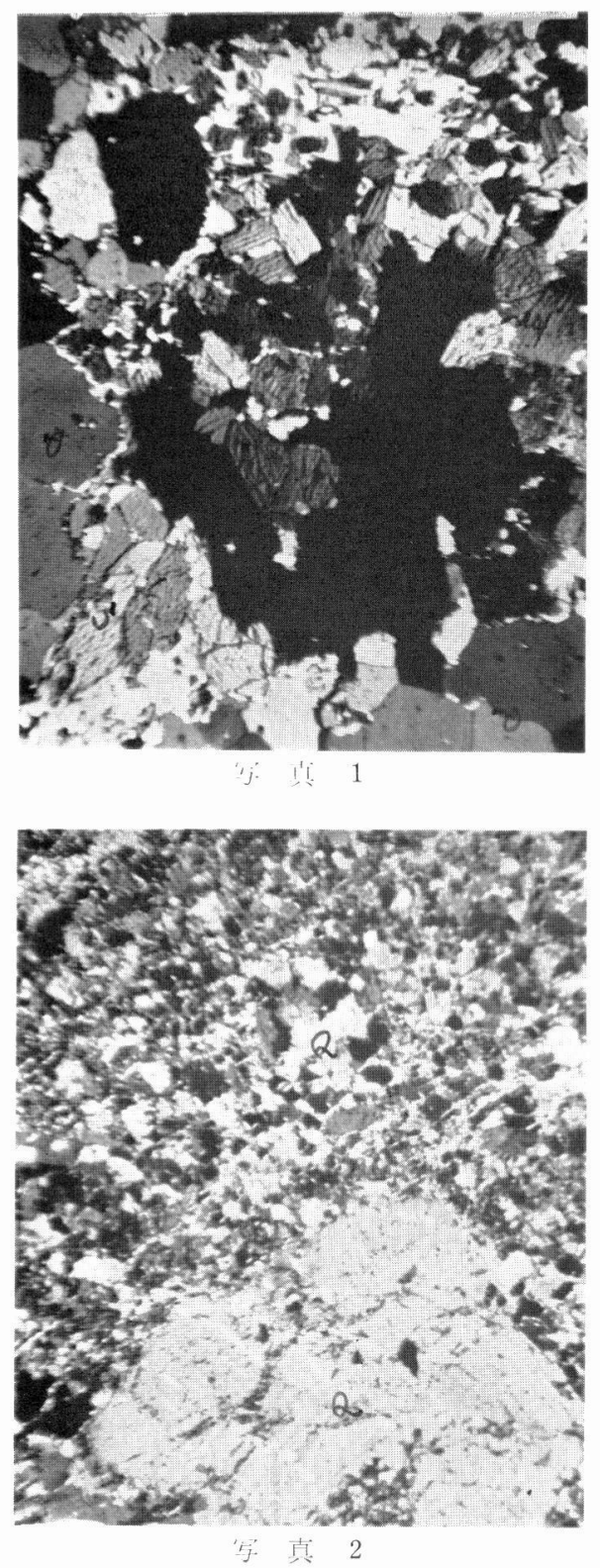
イの粒子は $0.0 \mathrm{n} . \mathrm{mm}$. 大のものが多く, $0 . \mathrm{n} . \mathrm{mm}$. 大のものも幾分存在す る。そしてセキェイの粒子間をパイロフィライト（セリサイトを含む）が充 填している状況で， らまく均一になっている。（写真 2 参照）

$\mathrm{X}$ 線回折より判定すればセリサイトが少なくパイロフィライトの量が多 く，これらの粒子は， $0.03 \mathrm{~mm}$ 以下ぐらいの細かいものである。

この鉱石の温度別による粉砕試料の焼結性は第 1 図に示す如きものであ る。

この鉱石を単味でレンガにして製鋼用取鍋レンガとして利用した結果，従 来の良質ロウ石レンガに比較して約 2 割, 耐用寿命の長いものが出来た。

この理由は, セキエイ, パイロフィライト, セリサイトの含有量も適当 で，使用時に高粘性の硝子層がうまく出来るものと考えられる。

このよらな結晶組織をもった鈗石はほかにも観察しており，特に五島鉱 山，勝光山などには多旦に存在していることを知っている。今後の活用が期 待される。

\section{5. 結霉}

ロウ石鉱床に産する鈗石はその主なる組成鉱物としてセキェイ，パイロフ イライト，セリサイト，ダイアスポアー，鉄化合物等で、これがまた一番論 議されるものである。

この鉱石を耐火物原料として検討する場合には先づ簡易に測定出来る耐火 度の測定をし，SK18 以上あるならば鉣物組成とその組織を調べる。特に 注意したいのはX線によって鈗石の鉱物を知ることは大切なことではある が，それ以上に大切なことは鉱石の組織を十分調べることである。極言すれ ば耐火度を测定し次に組織を観察すればこの鉣石はどのように利用出来るか の見当がつくということが出来る。

今後の研究問題は珪化帯の部分で, 少量存在するセリサイト, パイロフィ ライト, カオリナイト等の鉱物との共存況態がどのようであるかといらこと によって利用活用方面が考えられることになるであろら。 